\title{
Diversity of Pythium spp. associated with soybean damping-off, and management implications by using foliar fungicides as seed treatments
}

\author{
Shrishail S. Navi* (D), Tra Huynh, Chase G. Mayers and Xiao-Bing Yang
}

\begin{abstract}
Soybean (Glycine max) seedlings with symptoms of Pythium damping-off were collected in northeastern lowa soybean fields and processed for isolation of the causal agents on both potato dextrose agar (PDA) and pimaricin-, ampicillin-, rifampicin-, and pentachloronitrobenzene (PARP)-containing media. Isolates were identified based on morphological characteristics, growth rates, along with sequence data for the nuclear rDNA ITS1-5.8S-ITS2 region (ITS barcode). Nine isolates were identified via NCBI BLASTn search of sequences available in GenBank: one isolate of Pythium orthogonon; three isolates of $P$. inflatum; two isolates of $P$. ultimum var. ultimum; one isolate of $P$. torulosum; and two isolates of $P$. ultimum var. ultimum or $P$. ultimum var. sporangiferum. Pathogenicity of all the nine isolates, along with a positive control (P. irregulare), was tested in greenhouse conditions on soybean variety Pioneer 22T61R. Soybean seeds were planted in potting mixture inoculated with Pythium inoculum fermented on sterilized proso millet grains. The Pythium spp. were subsequently re-isolated from symptomatic plants. Average incidence of Pythium damping-off across isolates was $27.4 \%$ but varied among isolates, ranging from 1.2 to $79.8 \%$. Among the Pythium spp. collected in this single location, the most aggressive isolate was selected to test the efficacy of seed treatments using foliar fungicides in artificially-inoculated field conditions. Out of the eight tested foliar fungicides, six of them significantly suppressed damping-off compared with the untreated control. The average yield advantage of foliar fungicides as seed treatments was $0.23 \mathrm{mt}$ (metric ton)/ha (ranged from 0.15 to $0.31 \mathrm{mt} / \mathrm{ha}$ ) over the untreated control, with a corresponding economic advantage of $\$ 90.69$ (range $\$ 60.5$ to $\$ 123.9 / \mathrm{ha}$ ) based on soybean price at $\$ 397 / \mathrm{mt}$ as of September 30, 2017. Our findings suggest a potential for using foliar fungicides as seed treatments to control Pythium damping-off, and provide an alternative solution for managing resistance to metalaxyl/mefenoxam seed treatments in soybean production.
\end{abstract}

Keywords: Pythium damping-off, Soybean, Foliar fungicides, Seed treatments

\section{Background}

Worldwide more than 200 pathogens affect soybean (Glycine max [L.] Merr.), of which at least 35 are considered economically important (Hartman 2015). In Iowa these include several species in the genus Pythium (Oomycota) that cause damping-off and root rot symptoms in soybean seedlings. Pythium spp., which have very wide host range including grasses and a wide variety of dicotyledonous plants (Waterhouse and

\footnotetext{
* Correspondence: ssnavi@iastate.edu

Department of Plant Pathology and Microbiology, lowa State University, Ames, lowa, USA
}

Waterston 1964), cause problems in stand establishment, reduce seedling emergence, kill emerged seedlings, and reduce plant vigor (Kirkpatrick et al. 2006; Broders et al. 2009). One of the biggest threats for US soybean growers is the rapid speed at which Pythium attacks soybean seed; the dormant propagules (oospores) of Pythium spp. germinate in response to seed and root exudates and can infect seeds within 90 min of planting (Stranghellini and Hancock 1971). Infection by Pythium spp. leads to seed rot and the premature weakening and death of developing seedlings, referred to as damping-off (Kirkpatrick et al. 2006). Cooler soil temperatures and 
higher soil moisture content promote infection (Brown and Kennedy 1966; Biesbrock and FFJr 1970a, b; Yang 2002; Matthiesen et al. 2016). Other important soil-borne pathogens that cause soybean seedling diseases include species of the oomycete genus Phytophthora (Erwin and Ribeireo 1996), as well as the fungal genera Rhizoctonia (Yang 1999), and Fusarium (Díaz Arias et al. 2013).

Between 1996 and 2009, totaled across 28 US states (Wrather and Koenning 2009; Koenning and Wrather 2010), soybean seedling diseases caused an average annual yield loss of 32.9 million bushels $(0.90$ million metric tons, mmt), ranging from 12.3 million bushels (0.34 mmt) in 1999 to 55.5 million bushels (1.51 $\mathrm{mmt}$ ) in 2009. This represents significant economic losses due to soybean seedling diseases, ranging from $\$ 67.60$ million in 1999 to $\$ 779.92$ million in 2008, based on soybean prices at $\$ 201.67 / \mathrm{mt}$ and $\$ 522.83 /$ $\mathrm{mt}$, respectively (https://ycharts.com/indicators/us soybean_price_world_bank).

The use of fungicide seed treatments in soybean increased from 8\% of plantings in 1996 and 30\% in 2008 (Munkvold 2009), to $60 \%-70 \%$ in 2014 (USB 2014), corresponding with global growth of the seed treatment market for soybean and other crops (Anon 2017; Wellesley 2013). Increased cost of seeds and early planting in spring may be a driving force for such changes. Fungicide seed treatments are especially effective in preventing or reducing damage from seed- or soil-borne pathogens that cause seed decay, seedling blights, and root rots (Sweets 2006), and thus result in a significant yield increase in fields with high seedling disease risk (Yang 2009). In optimum conditions, seed treatments can provide significant return on value; for example, Poag et al. (2005) determined that seed treatments costing less than $\$ 8.65 /$ ha averaged a return of $\$ 43.71 /$ ha due to protection against soil-borne and seed-borne pathogens in Arkansas. However, mixed results have been observed from the use of seed treatments in different environments and under different levels of pathogen pressure (Bradley et al. 2001; Dorrance and McClure 2001; Dorrance et al. 2003a; Bradley 2008). Most available fungicides are labeled for use against specific pathogenic fungi (e.g. Rhizoctonia, Fusarium, and Macrophomina), but some (i.e. oomicides) are intended for use against oomycetes (e.g. Phytophthora and Pythium) (Sweets 2006). Bradley (2010) suggested combining fungicides effective against oomycetes (mefenoxam or metalaxyl) with at least one other fungicide (e.g. fludioxonil, trifloxystrobin, pyraclostrobin, or ipconazole) to provide additional control of Fusarium, Rhizoctonia, or other fungal pathogens.

A diversity of Pythium spp. have been associated with diseases of soybean and corn seedlings in Iowa
(Robertson 2012, Robertson et al. 2013), and a diverse array of oomycete species cause problems in soybean across North America (Rojas et al. 2017a, 2017b). These include additional pathogenic species of Pythium which have not yet been reported in Iowa, but may be present and were missed in the small number of previous surveys. In Iowa, as well as elsewhere in the North Central Region, the protection of seedlings from Phytophthora/ Pythium damping-off and Rhizoctonia/Fusarium root rot mainly comes in the form of seed treatments (chemical and biological) specifically formulated for application to seeds (Bradley 2008). Interestingly, Powelson and Inglis (1999) identified a potential alternate use of foliar fungicides as seed treatments in potato. Considering the potentially incomplete understanding of the diversity of Pythium spp. present in Iowa, potentially significant losses due to the seedling disease they cause, and a need for alternative management strategies, we set three broad objectives in this work: (a) isolate and characterize a diversity of Pythium spp. associated with soybean seedlings in Iowa; (b) test the pathogenicity of representative isolates; and (c) field test fungicide seed treatments with Quinone outside inhibitors (QoI), Demethylation inhibitors (DMI) and Succinate dehydrogenase inhibitors (SDHI), against the most aggressive available isolate from the pathogenicity test.

\section{Results}

\section{Soybean seedlings display Pythium damping-off} symptoms in the field trial

Of the various planting dates, the June 8th plantings of varieties Pioneer 22T69R and Pioneer 25T51R showed symptoms of damping-off (Fig. 1), whereas Pioneer $92 Y 75$ for the most part did not show damping-off. The three varieties germinated and emerged normally on

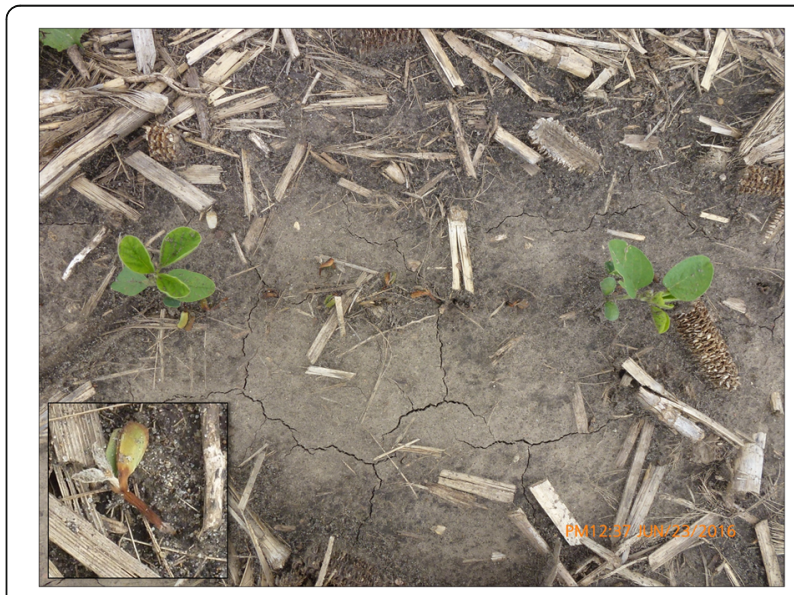

Fig. 1 Field symptoms of Pythium damping-off observed during June 2016 at Northeast Research and Demonstration Farm, Nashua, lowa. Damped-off soybean seedlings are seen between two healthy seedlings and an inset is close up image of damping-off 
June 13th, but after six days of rain starting on June 9 $(15.2 \mathrm{~cm})$, seedlings in the lower portion of the replications on the downhill side of the field began to show symptoms of damping-off.

\section{Pythium isolates collected in lowa comprise several different species or subspecies}

Out of 16 isolates that produced oospores and sporangia (Fig. 2), and displayed culture morphology of Pythium spp., nine were selected for ITS barcoding due to differences in culture morphology. ITS sequences obtained from these isolates matched Pythium sequences in GenBank: "C1-2" had 99\% (855/864 bases) identity with Pythium orthogonon HQ643723; isolates "D2-1", "D12", and "A2-1" had 100\% (822/822, 814/814, and 823/ 823 bases, respectively) identity with $P$. inflatum AY598626; isolates " $2-3$ " and "1-4" had 100\% (876/876 and $870 / 870$ bases, respectively) identity with $P$. ultimum var. ultimum KU210728; isolate "- 4" had 100\% (826/826 bases) identity with $P$. torulosum AY598624; isolate "-?" had $100 \%$ identity with both P. ultimum var. ultimum KU211001 (662/662 bases) and P. ultimum var. sporangiferum KT429653 (659/659 bases); and isolate "-??" had $100 \%$ identity (886/886 bases) with the sequence obtained from isolate "-?"

\section{Pythium isolates differ in colony morphology and growth rates}

Colony growth rate in diameter ( $\mathrm{mm} /$ day) (Table 1$)$ and visual assessment of colony morphology (Fig. 3) indicated variability among the isolates. At an early stage of incubation (1-4 days after incubation), there were

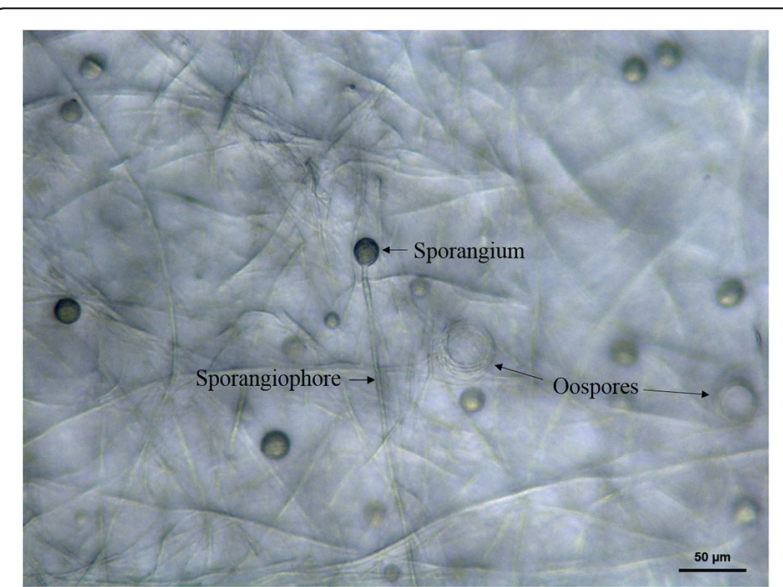

Fig. 2 Hyphae, sporangia, sporangiophore and oospores imaged with a Zeiss Axio Zoom V16 microscope using base illumination with relief contrast, dark-field and bright-field modes and epi-illumination with a Schott LED ring light to catch intact images of fruiting bodies of Pythium irregulare. This image was captured without opening culture plate at Bessey Microscope facility (currently, Microscopy and Nanolmaging Facility), lowa State University significant differences in radial growth among a few isolates, but such difference disappeared at 5 days post incubation (Table 1).

\section{Pythium isolates display pathogenicity diversity}

Pathogenicity of all the nine isolates, along with a positive control ( $P$. irregulare), was proven in greenhouse conditions on soybean variety Pioneer 22T61R. Seeds were planted in potting mixture mixed with individual Pythium isolates fermented on sterilized millet grains. Average Pythium damping-off incidence across isolates was $27.39 \%$, ranging from $1.2 \%$ in isolate "A2-1" ( $P$. inflatum $)$ to $79.8 \%$ in isolate " $2-3$ " ( $P$. ultimum var. ultimum). Significantly $(P<0.05)$ highest incidence was observed in isolate 2-3 (Table 2). There was no significant difference in damping-off incidence among isolates "1-4" (58.3\%), “?" (58.3\%) and "??" (51.2\%). Also, these isolates showed significantly higher incidence (\%) compared with the positive control $P$. irregulare of $14.3 \%$ (Table 2). Other five isolates (D1-2, $\mathrm{C} 1-2,-4, \mathrm{D} 2-1$, and A2-1) showed less than 5\% incidence with no significant differences among these isolates and with the positive control (Table 2; Fig. 4).

\section{Foliar fungicides effectively control soybean Pythium damping-off}

An attempt was made to test the efficacy of QoI, DMI and SDHI fungicides in control of Pythium damping-off. Though, damping-off incidence in field test was not as high as that in control conditions. An average incidence in fungicide treated plots was $0.68 \%$ (ranged from $0.31 \%$ to $1.07 \%$ ), compared to the untreated control of $1.21 \%$ (Table 3). Similarly, an average yield in fungicide treated plots was $5.28 \mathrm{mt} / \mathrm{ha}$ (ranged from 5.20 to $5.36 \mathrm{mt} / \mathrm{ha}$ ) compared with $5.05 \mathrm{mt} / \mathrm{ha}$ in the untreated control (Table 3). Yields were significantly $(P<0.05)$ higher in plots treated with Aproach, Priaxor, Quadris, and Stratego YLD compared with the untreated control (Table 3). Also, yields were numerically higher in plots treated with Endura, Evito, and Headline compared with the control, but statistically no difference (Table 3). An average yield advantage across fungicide treated plots compared with that of untreated plots was $0.23 \mathrm{mt} / \mathrm{ha}$ (range from $0.15 \mathrm{mt} / \mathrm{ha}$ to $0.31 \mathrm{mt} / \mathrm{ha}$ ), and corresponding economic advantage was USD 90.69/ha (range from $\$ 60.50 /$ ha to $123.9 / \mathrm{ha}$ ) based on soybean price $\$ 397 / \mathrm{mt}$ on September 30, 2017 (https://ycharts.com/indicators/ us_soybean_price_world_bank).

\section{Discussion}

A diversity of Pythium spp. have been associated with soybean and corn seedling diseases across North America including Iowa (Robertson 2012; Robertson et al. 2013; Matthiesen et al. 2016; Rojas et al. 2017a, 
Table 1 Radial growth rate ( $\mathrm{mm} /$ day) of Pythium isolates recorded at $24 \mathrm{~h}$ interval for 5 days

\begin{tabular}{|c|c|c|c|c|c|}
\hline \multirow[t]{2}{*}{ Pythium isolates } & \multicolumn{5}{|c|}{ Radial growth rate ( $\mathrm{mm} /$ day) over 5 days of incubation ${ }^{*}$} \\
\hline & 1 & 2 & 3 & 4 & 5 \\
\hline P. inflatum & $13.5 \mathrm{dc}$ & $31.0 \mathrm{dc}$ & $47.0 \mathrm{~b}$ & $62.5 \mathrm{ba}$ & $63.8 \mathrm{a}$ \\
\hline P. ultimum var. ultimum & $43.5 a$ & $83.8 \mathrm{a}$ & $85.0 \mathrm{a}$ & $85.0 \mathrm{a}$ & $85.0 \mathrm{a}$ \\
\hline P. orthogonon & $36.0 b$ & $72.0 \mathrm{ba}$ & $85.0 \mathrm{a}$ & $85.0 \mathrm{a}$ & $85.0 \mathrm{a}$ \\
\hline P. torulosum & $0.0 \mathrm{e}$ & $61.3 b$ & $85.0 \mathrm{a}$ & $85.0 \mathrm{a}$ & $85.0 \mathrm{a}$ \\
\hline P. inflatum & $0.0 \mathrm{e}$ & $15.8 d$ & $46.8 b$ & $57.5 \mathrm{ba}$ & $63.8 \mathrm{a}$ \\
\hline P. inflatum & $8.5 d$ & $26.0 \mathrm{dc}$ & $43.3 b$ & $62.0 \mathrm{ba}$ & $85.0 \mathrm{a}$ \\
\hline P. ultimum var. ultimum & $11.0 \mathrm{dc}$ & $24.0 \mathrm{dc}$ & $35.5 b$ & $48.0 \mathrm{~b}$ & $62.3 a$ \\
\hline P. ultimum var. ultimum or P. ultimum var. sporangiferum & $16.0 \mathrm{c}$ & $33.3 \mathrm{c}$ & $52.0 \mathrm{~b}$ & $71.3 \mathrm{ba}$ & $77.5 \mathrm{a}$ \\
\hline P. ultimum var. ultimum or P. ultimum var. sporangiferum & $8.0 \mathrm{~d}$ & $25.3 \mathrm{dc}$ & $43.5 b$ & 61.0ba & $85.0 \mathrm{a}$ \\
\hline
\end{tabular}

"Results are average of 4 replications. Means within column followed by the same letter(s) are not significantly different from each other at $5 \%$ level of significance $(P<0.05)$

2017b). Earlier studies (Zhang et al. 1998; Zhang and Yang 2000) on soybean and corn rotation fields in Iowa found Pythium populations with four major species $(P$. ultimum, $P$. torulosum, $P$. paroecandrum, and P. spinosum), of which $P$. torulosum was the most frequently isolated species. In this study, nine Pythium isolates were obtained comprising five different species or subspecies, of which two ( $P$. orthogonon, and $P$. ultimum var. sporangiferum) appear to be new reports for Iowa; the remaining species have been previously reported on either soybean or corn (Robertson et al. 2013; Matthiesen et al. 2016; Rojas et al. 2017a, 2017b). The fact that a sample of nine isolates yielded five species/subspecies agrees with previous studies and suggests that Pythium species composition is typically diverse within fields.

Management of Pythium damping-off mainly involves seed treatments with either chemical or biological products (Munkvold 2009; Coker et al. 2010), apart from cultural practices (Coker et al. 2001), and host-plant resistance (Dorrance et al. 2003b; Rosso and Rupe, 2005; Bates et al. 2008). Recently, Carmona et al. (2018) reported products of Spraytec fertilizers containing potassium and manganese phosphites as an alternative to fungicide seed treatments to control soybean damping-off caused by $P$. aphanidermatum, $P$. irregulare and P. ultimum in Argentina.

Although there are no known soybean varieties resistant to Pythium damping-off on the market, there are varieties differing in susceptibility to damping-off. Apart from soybean, Pythium spp. can infect a very wide range of hosts, including corn, and the oospores of Pythium are long lived in soil. Hence, the effectiveness of crop rotation (particularly corn in Iowa) in managing Pythium damping-off is limited.

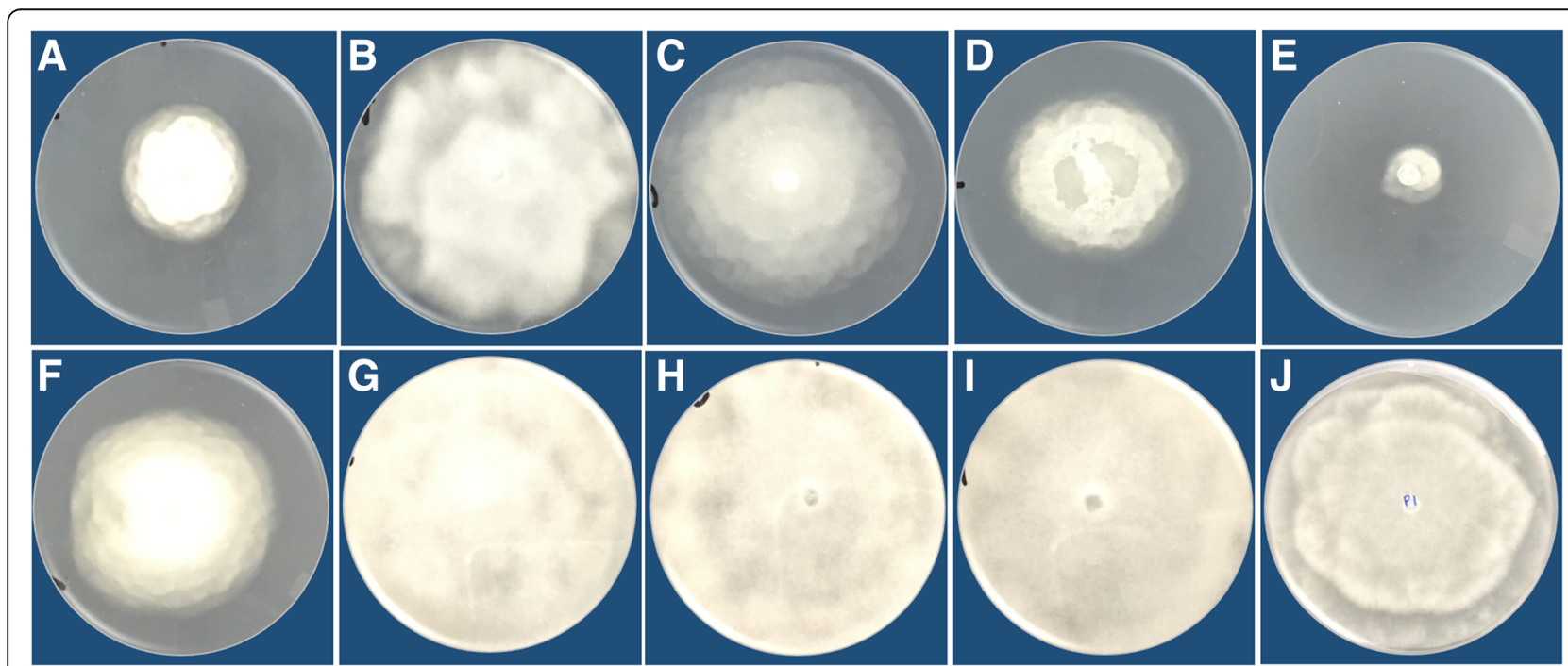

Fig. 3 Colony morphology of Pythium isolates at 3 days after incubation on PDA. P. inflatum (a, e and $\mathbf{f})$, P. ultimum var. ultimum (b), P. orthogonon (c), P. torulosum (d), P. ultimum var. ultimum (g), P. ultimum var. ultimum or P. ultimum var. sporangiferum $(\mathbf{h}$ and $\mathbf{i})$, and P. irregulare (j) incubated under a $12 \mathrm{~h}$ light $/ 12 \mathrm{~h}$ dark cycle at $23 \pm 1{ }^{\circ} \mathrm{C}$ 
Table 2 Damping-off incidence (\%) of Pythium isolates on soybean variety Pioneer 22T61RR in pathogenicity tests conducted in greenhouse

\begin{tabular}{|c|c|c|c|c|c|}
\hline Cups labeled & Isolate No. & Identity with GenBank (\%) & GenBank Accession No. & Pythium spp. & Incidence $(\%)^{y}$ \\
\hline 1 & D1-2 & $100 \%$ (814/814 bases) & AY598626 & P. inflatum & $2.4 c$ \\
\hline 2 & $1-4$ & $100 \%$ (870/870 bases) & KU210728 & P. ultimum var. ultimum & $58.3 b$ \\
\hline 3 & C1-2 & $99 \%$ (855/864 bases) & HQ643723 & P. orthogonon & $3.6 c$ \\
\hline 4 & -4 & $100 \%$ (826/826 bases) & AY598624 & P. torulosum & $2.4 c$ \\
\hline 5 & D2-1 & 100\% (822/822 bases) & AY598626 & P. inflatum & $2.4 c$ \\
\hline 6 & $A 2-1$ & $100 \%$ (823/823 bases) & AY598626 & P. inflatum & $1.2 \mathrm{c}$ \\
\hline 7 & $2-3$ & 100\% (876/876 bases) & KU210728 & P. ultimum var. ultimum & $79.8 a$ \\
\hline 8 & $?$ & $\begin{array}{l}100 \%(662 / 662 \text { bases }) \\
100 \%(659 / 659 \text { bases })\end{array}$ & $\begin{array}{l}\text { KU211001 } \\
\text { KT429653 }\end{array}$ & $\begin{array}{l}\text { P. ultimum var. ultimum } \\
\text { or P. ultimum var. sporangiferum }\end{array}$ & $58.3 b$ \\
\hline 9 & $? ?$ & 100\% (886/886 bases) & KU211001 & $\begin{array}{l}\text { P. ultimum var. ultimum or } \\
\text { P. ultimum var. sporangiferum }\end{array}$ & $51.2 \mathrm{~b}$ \\
\hline 10 & $\mid A-G r-21^{z}$ & & & P. irregulare & $14.3 c$ \\
\hline
\end{tabular}

${ }^{\times}$Results are average of 12 replications with each replication planted with 7 seeds. ${ }^{{ }}$Means within column followed by the same letter(s) are not significantly

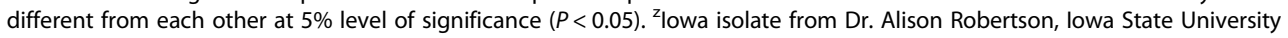

According to Munkvold (2009), seed treatments with strobilurin fungicides have effects on plant physiology. Such fungicides in foliar formulations have played a major role in marketing in some crops, and this has impacted seed treatments as well. Also, some of the trademarks like Plant Health ${ }^{\text {Tx }}$ (BASF) and Plant Performance $^{\mathrm{mm}}$ (Syngenta) have been coined to describe the direct benefits on plant physiology (Munkvold 2009).
Similar to strobilurin group, triazoles and other groups of fungicides have an effect on physiology of plants (Tripathi et al. 1980; Wu and Von Tiedemann, 2001). Some of the physiological changes that occur in plants are increased levels of abscisic acid (Grossmann et al. 1999) and antioxidative potential (Wu and Von Tiedemann, 2001), tolerance to environmental stresses (Gerhard et al. 1999; Beck et al. 2002; Reade et al. 2003),

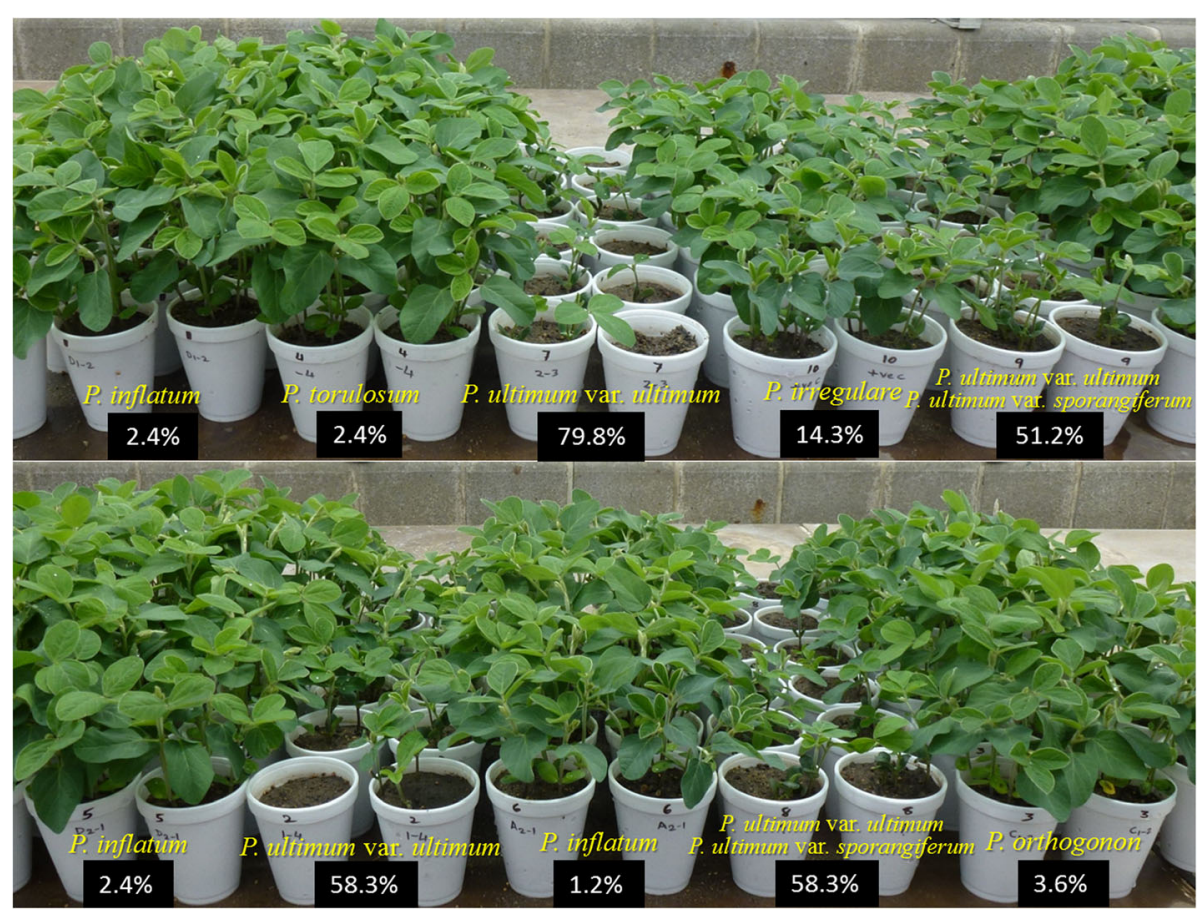

Fig. 4 Pathogenicity test results of Pythium spp. in greenhouse. Soybean seeds (cultivar: Pioneer 22T61RR) were planted in white foam cup (237 mL) containing potting mixture mixed with individual Pythium isolates fermented on sterilized millet grains. Each isolate was tested in 12 cups and each cup with seven seeds 
Table 3 Effects of using commercial foliar fungicides as seed treatments on stand count, vigor, damping-off incidence (\%), and yields in a soybean field inoculated with Pythium ultimum var. ultimum at West Curtiss Research Farm, lowa State University, Ames, lowax

\begin{tabular}{|c|c|c|c|c|c|c|}
\hline \multirow[t]{2}{*}{ Fungicides } & \multirow{2}{*}{$\begin{array}{l}\text { Stand } \\
\text { count }\end{array}$} & \multirow{2}{*}{$\begin{array}{l}\text { Plant } \\
\text { vigory }^{y}\end{array}$} & \multirow{2}{*}{$\begin{array}{l}\text { Damping-off } \\
\text { Incidence (\%) }\end{array}$} & \multirow{2}{*}{$\begin{array}{l}\text { Yield } \\
\text { (mt/ha) }\end{array}$} & \multicolumn{2}{|c|}{ Advantage over control } \\
\hline & & & & & Yield (mt/ha) & Economic (USD/ha) \\
\hline Aproach & $551.5 \mathrm{a}$ & $8.8 \mathrm{ba}$ & $1.07 \mathrm{ba}$ & $5.36 a$ & 0.31 & 123.9 \\
\hline Endura & $588.0 \mathrm{a}$ & $9.0 a$ & $0.59 \mathrm{edc}$ & $5.22 \mathrm{ba}$ & 0.17 & 67.8 \\
\hline Evito & $563.0 \mathrm{a}$ & $8.8 \mathrm{ba}$ & 0.62ede & $5.20 \mathrm{ba}$ & 0.15 & 60.5 \\
\hline Headline & $588.3 a$ & $9.0 a$ & $0.51 \mathrm{ed}$ & $5.24 \mathrm{ba}$ & 0.19 & 74.9 \\
\hline Priaxor & $577.5 a$ & $9.0 a$ & $0.31 \mathrm{e}$ & $5.33 a$ & 0.28 & 109.4 \\
\hline Quadris & $570.0 a$ & $8.5 \mathrm{ba}$ & $0.80 \mathrm{bdc}$ & $5.31 \mathrm{a}$ & 0.25 & 100.9 \\
\hline Stratego YLD & $575.3 a$ & $8.8 \mathrm{ba}$ & $0.88 \mathrm{bac}$ & $5.31 a$ & 0.26 & 103.9 \\
\hline Sercadis & $574.5 a$ & $8.8 \mathrm{ba}$ & $0.63 \mathrm{edc}$ & $5.26 \mathrm{ba}$ & 0.21 & 84.2 \\
\hline Control & $570.8 \mathrm{a}$ & $8.3 b$ & $1.21 \mathrm{a}$ & $5.05 b$ & 0 & 0 \\
\hline
\end{tabular}

${ }^{\times}$Results are average of 4 replications each with $16.2 \mathrm{~m}^{2}$ plot in RCBD design. Means within column followed by the same letter(s) are not significantly different from each other at $5 \%$ level of significance $(P<0.05)$. ${ }^{y}$ based on a $1-9$ scale at growth stage $V 5$, where $1=$ poor and $9=$ excellent. ${ }^{z}$ based on soybean price $\$ 397 /$ $\mathrm{mt}$ on Sept 30, 2017. (https://ycharts.com/indicators/us_soybean_price_world_bank)

and plant-defense responses (Herms et al. 2002; Conrath et al. 2004).

Yields in plots treated with Endura, Evito, Headline and Sercadis were not significantly different over the untreated control, but certainly these treatments had direct effects in significantly reducing damping off incidence as well as on plant physiology which may have enhanced yield from $0.15 \mathrm{mt} / \mathrm{ha}$ in Evito to $0.21 \mathrm{mt} / \mathrm{ha}$ in Sercadis treated plots compared with the untreated control (Table 3). On the contrary, plots treated with Aproach and Stratego YLD showed no significant impact on damping off incidence, but certainly showed yield advantage of $0.31 \mathrm{mt} / \mathrm{ha}$ and $0.26 \mathrm{mt} / \mathrm{ha}$ respectively over the untreated control (Table 3). Significantly, the lowest damping off incidence was observed in Priaxor treated plots but yields were $0.03 \mathrm{mt} / \mathrm{ha}$ less than the Aproach. Percent incidence of Pythium damping-off in Aproach treated plots was highest among the fungicides tested plots $(0.14 \%$ less than the untreated plots), but the yield advantage was also highest among the fungicides tested (Table 3), suggesting that Aproach fungicide may not have direct effect on Pythium but of plant performance (Table 3).

There are reports of Pythium developing resistance or showing insensitivity to products with an active ingredient of metalaxyl in seed treatments (Dorrance 2014; Anon 2015). Therefore, fungicides tested for soybean seed treatments were labeled for foliar application and were not labeled to control Pythium damping-off. Aproach has not been labeled either foliar or seed treatments against Pythium damping-off, Rhizoctonia root rot and sudden death syndrome. In this study, the product has reduced the incidence of Pythium damping-off by $0.14 \%$ and showed $0.31 \mathrm{mt} / \mathrm{ha}$ yield advantage compared with the untreated control (Table 3). According to Arysta LifeSciences, Evito foliar spray provides outstanding control of Rhizoctonia aerial blight in addition to several foliar diseases in soybean. In the current study, Evito seed treatments significantly $(P<$ $0.05)$ reduced Pythium damping-off and showed $0.15 \mathrm{mt} /$ ha yield advantage over the untreated control (Table 3).

Of the three BASF products (Headline, Priaxor, and Sercadis) tested, Headline seed treatments significantly $(P<0.05)$ reduced damping-off and showed $0.19 \mathrm{mt} / \mathrm{ha}$ yield advantage over the untreated control (Table 3), although it was not labeled for Pythium control. According to BASF, Headline, applied in-furrow on corn and soybean, can control soil-borne Rhizoctonia while it improves seedling health with more rapid and uniform emergence even under cold and wet conditions. In addition, the EC formulation can be tank-mixed with a liquid fertilizer for easy application. Interestingly, yield advantages in Headline seed treatment are similar to Headline foliar spray either solo or in combination with other fungicides and insecticides across 11 seasons (Navi et al. 2015). However, yield advantages in Headline spray were higher than seed treatments with an average yield advantage of $8.27 \mathrm{mt} / \mathrm{ha}$ (range from 3.37 to $13.24 \mathrm{mt} /$ ha), even under low disease pressure (Navi et al. 2015). Although, no significant advantage of Headline (solo or combination) in plots against sudden death syndrome and white mold, significant $(P<0.05)$ yield increase was observed over unsprayed controls indicating plant health benefits of spray (Navi et al. 2015).

Similarly, Priaxor, as a foliar spray is effective against Alternaria leaf spot, anthracnose, rust, brown spot, Cercospora blight, frogeye leaf spot, pod and stem blight, Rhizoctonia aerial blight, white mold and southern blight as per the BASF product label. When the product was tested as seed treatment against Pythium damping-off, it significantly reduced the incidence and increased yield by $0.28 \mathrm{mt} / \mathrm{ha}$ compared with 
the untreated control (Table 3). Present yield advantage in Priaxor seed treatment is in agreement with its foliar spray studies in significantly reducing white mold and increasing yields (Navi 2014a, 2014b). Although Sercadis of BASF, is not labeled for soybean diseases but for sheath blight of rice caused by Rhizoctonia solani, in seed treatment tests, Sercadis has significantly reduced damping-off incidence with a yield advantage of 0.21 $\mathrm{mt} / \mathrm{ha}$ (Table 3).

According to Syngenta, Quadris is a broad spectrum, preventative fungicide with systemic and curative properties recommended for the control of many plant diseases. The fungicide can also be applied as a foliar spray in alternating spray programs or in tank mixes with other registered crop protection products. Quadris seed treatment showed significant suppression of damping-off with a yield advantage of $0.25 \mathrm{mt} / \mathrm{ha}$ compared with the untreated control (Table 3).

As per Bayer CropScience, Stratego YLD controls Alternaria leaf spot, anthracnose, rust, brown spot, Cercospora blight, frogeye leaf spot, pod and stem blight, powdery mildew, and Rhizoctonia aerial blight. Although foliar spray of Stratego YLD did not show significant effect on sudden death syndrome, white mold and yields (Navi 2013, 2014a), seed treatments in the current study showed significant yield advantage, and $0.33 \%$ higher suppression of Pythium damping-off compared with the untreated control (Table 3). Our finding is the first report on the new use of this fungicide. Studies to investigate and strengthen the effect of biocontrol agents on some major yield reducing soil borne pathogens are underway.

\section{Conclusions}

In summary, in addition to finding a diversity of Pythium species at a single location, we report at least two new Pythium species in Iowa. Further studies to identify diversity of species of Pythium, Rhizoctonia, Phytophthora and Fusarium, in soils are needed. Most of the foliar fungicides tested for seed treatments show encouraging results. Our findings demonstrate the potential of using foliar fungicides as seed treatments to control Pythium damping-off, which strengthens management options to minimize losses due to seedling diseases with existing products on the market.

\section{Methods \\ Isolation and identification of Pythium spp. from soybean seedlings}

Sixty symptomatic soybean seedlings were collected in June 2016 from a planting date $\times$ variety maturity study trial at Northeast Research Demonstration Farm, Nashua, Iowa. For surface disinfection, seedlings were rinsed with deionized water, soaked in $20 \mathrm{~mL}$ of $1 \%$ sodium hypochlorite solution for three minutes in two 9 $\mathrm{cm}$ disposable Petri dishes, and rinsed four times in four separate disposable Petri dishes containing sterile deionized water. After disinfection, the seedlings were cut into approximately $1-\mathrm{cm}$-long pieces using sterilized single edge industrial blade, and transferred with sterile forceps onto Petri dishes of potato dextrose agar (PDA) or PARP (pentachloronitrobenzene $50 \mathrm{mg}$, ampicillin 250 $\mathrm{mg}$, rifampicin $10 \mathrm{mg}$ and pimaricin $5 \mathrm{mg} / \mathrm{L}$ ) (Jeffers and Martin 1986), sealed with Parafilm, and incubated at $23 \pm 1{ }^{\circ} \mathrm{C}$ under a $12 \mathrm{~h}$ light $/ 12 \mathrm{~h}$ dark cycle for $3-4$ days. A total of 30 seedlings were plated on PDA and another 30 on PARP. Filamentous fungal colonies emanating from the peripheral edge of seedling pieces were subcultured on PDA. Each isolate was subcultured and purified by successive hyphal tip transfer. Isolates from PDA and PARP plates were labeled numerically and alphabetically, respectively. Isolates were preliminary characterized based on colony morphology, growth rate $(\mathrm{mm} /$ day), and the microscopic observation of oospores and sporangia that are typical of Pythium spp.

Putative Pythium isolates were grown on PDA for 2-4 days (depending on growth rate) at $23 \pm 1{ }^{\circ} \mathrm{C}$, and total DNA was extracted with PrepMan ${ }^{\circ}$ Ultra and the manufacturer's suggested protocol (Applied Biosystems, Foster City, CA). The nuclear rDNA ITS1-5.8S-ITS2 region (ITS barcode) was amplified using the universal primers ITS6 and ITS4 (Cooke et al. 2000). Sanger Sequencing of amplified DNA was performed by using the same primers at the Iowa State University DNA Facility. Forward and reverse sequences were assembled with Sequence Navigator v 1.0.1 (Applied Biosystems) and compared against the NCBI GenBank using NCBI BLASTn (National Center for Biotechnology Information).

\section{Colony morphological observation and growth rate of Pythium isolates}

A $6 \mathrm{~mm}$ culture plug was taken from the edge of an actively growing colony of a Pythium isolate and inoculated onto the center of a PDA plate $(9 \mathrm{~cm}$ in diameter). Each plate was sealed with parafilm and incubated under a $12 \mathrm{~h}$ light $/ 12 \mathrm{~h}$ dark cycle at $23 \pm 1{ }^{\circ} \mathrm{C}$ for 5 days. During the incubation period, mycelial radial growth rate $(\mathrm{mm} /$ day) was recorded at $1,2,3,4$, and 5 days after plating (DAP). There were 9 treatments, and each treatment had four replications. Variability in colony morphology among the isolates was recorded based on visual and microscopic assessment for the confirmation of the genus Pythium.

\section{Pathogenicity tests of Pythium spp.}

Inoculum from each Pythium isolate was reproduced on millet grains by transferring 4 culture plugs to a $500 \mathrm{~mL}$ conical flask containing $150 \mathrm{cc}$ of steam-sterilized millet 
grains and incubated for 10-12 days. Pathogenicity assays of Pythium isolates were performed using a previously reported method (Navi and Yang 2016). The pathogenicity of all nine isolates, along with a positive control ( $P$. irregulare isolate IA-Gr-21), was tested on soybean variety Pioneer 22T61R in greenhouse conditions in February-March 2017. Twelve cups per isolate were incubated on greenhouse benches in a $16 \mathrm{~h} /$ day light under a $400 \mathrm{~W}$ E-Ballast, Metal Halide type M59 bulb. During incubation, plants were watered twice daily to maintain moisture in cups. Stand count and damping-off count were recorded at 10 and 20 days after planting. Seedlings with damping-off symptoms were collected and rinsed in running deionized water. Attempts to re-isolate the inoculated Pythium spp. were re-performed as described above.

\section{Fungicides evaluation}

\section{Stock solution preparation}

A total of eight commercial foliar fungicides (Table 4) were evaluated for their effectiveness against Pythium damping-off. Under aseptic conditions, in a pre-disinfected NuAire class II type B2 biological safety cabinet, aliquots of each product (Table 4) were transferred separately to conical flasks containing $1 \mathrm{~L}$ sterilized deionized water (SDW). Each of these dilutions was thoroughly mixed by stirring on a Thermolyne magnetic stir plate for two minutes.

\section{Seed treatments}

Commercially untreated soybean seed (Pioneer 22T69R) was procured from DuPont Pioneer (1116 Giddings St, Kelley, IA 50134). Five $\mathrm{mL}$ of each fungicide stock solution (Table 4) was separately transferred with a sterile syringe to a $33 \mathrm{~cm} \times 39.6 \mathrm{~cm}$ Ziploc bag containing $1 \mathrm{~kg}$ seed and well-mixed for proper coating of the seeds.
Water-treated seed served as a control. The treated and untreated seeds were subsampled at 700 seeds in 8.5 $\mathrm{cm} \times 20.3 \mathrm{~cm}$ envelopes per replication of 4-row plots.

\section{Inoculum fermentation}

Pythium inoculum was increased on proso millet grains using the fermentation method of Navi and Yang (2016), but with Pythium isolates obtained in this study. Fermented Pythium inoculum was subsampled at $350 \mathrm{cc}$ per envelope $(8.5 \mathrm{~cm} \times 20.3 \mathrm{~cm})$ per 4-row plot (at $5 \mathrm{cc} /$ linear foot).

\section{Planting}

To assess efficacy of fungicide seed treatments against damping off, a trial was set up at West Curtiss Research Farm in Ames in a Randomized Complete Block Design (RCBD) with four replications, each $3.0 \mathrm{~m} \times 5.3 \mathrm{~m}$ in $76-\mathrm{cm}$ row spacing. Seeds from each individual treatment and the Pythium inoculum subsampled separately in envelopes were placed into a 4-row cone plot planter and planted using an ALMACO 4-Row SeedPro Precision Vacuum planter with an automatic cable winding trip system. Post-emergence herbicide was applied to plots when required.

\section{Evaluations}

Plots were evaluated for stand counts and plants showing damping-off symptoms at the 2 nd and 3rd week after planting (WAP). Also, the plots were evaluated for vigor rating at the V5 growth stage (Fehr et al., 1971; Pederson 2007) on a 1 (poor) to 9 (excellent) vigor rating scale. Disease incidence was calculated by the formula (infected plants $\times 100) \div$ total plants in each plot.

Table 4 List of foliar fungicides used in seed treatment tests in field against damping-off caused by Pythium ultimum var. ultimum in a soybean field artificially inoculated

\begin{tabular}{|c|c|c|c|c|c|c|}
\hline Fungicides & Dilutions used per liter ${ }^{a}$ & $\begin{array}{l}\text { Labeled spray } \\
\text { rates }(\mathrm{mL} / \mathrm{ha})^{\mathrm{b}}\end{array}$ & Active ingredient (\%) & Group name & FRAC code ${ }^{c}$ & Manufacturer \\
\hline Aproach 250SC & $3.1 \mathrm{~mL}$ & 438.2 & Picoxystrobin (22.5) & Qol & 11 & DuPont \\
\hline Endura* & $4.0 \mathrm{~g}$ & 293.6 & Boscalid (70) & $\mathrm{SDHI}$ & 7 & BASF \\
\hline Evito $480 \mathrm{SC}$ & $1.0 \mathrm{~mL}$ & 146.0 & Fluoxastrobin (40.3) & Qol & 11 & Arysta LifeSciences \\
\hline Headline 250EC & $3.1 \mathrm{~mL}$ & 438.2 & Pyraclostrobin (23.6) & Qol & 11 & BASF \\
\hline Priaxor 500SC & $2.1 \mathrm{~mL}$ & 292.2 & $\begin{array}{l}\text { Fluxapyroxad (14.33)+ } \\
\text { Pyraclostrobin (28.58) }\end{array}$ & Carboxamides + Qol & 7,11 & BASF \\
\hline Quadris 250FL & $3.1 \mathrm{~mL}$ & 438.2 & Azoxystrobin (22.9) & Qol & 11 & Syngenta \\
\hline Sercadis $3005 C$ & $1.4 \mathrm{~mL}$ & 197.1 & Fluxapyroxad (26.55) & Carboxamides & 7 & BASF \\
\hline Stratego YLD & $2.1 \mathrm{~mL}$ & 292.2 & $\begin{array}{l}\text { Prothioconazole (10.8)+ } \\
\text { Trifloxystrobin (32.3) }\end{array}$ & $\mathrm{DMI}+\mathrm{Qol}$ & 3,11 & Bayer \\
\hline
\end{tabular}

${ }^{a}$ Dilutions were based on the ${ }^{b}$ labeled spray rates mixed in $140 \mathrm{~L}$ of water. $\mathrm{SC}=$ Suspension concentrate, ${ }^{*}=\mathrm{Granular}$; $\mathrm{EC}=\mathrm{Emulsifiable} \mathrm{concentrate,} \mathrm{FL}=\mathrm{Flowable}$ Qol fungicides = Quinone outside inhibitors, DMI fungicides = Demethylation inhibitors, SDHI = Succinate dehydrogenase inhibitors, ${ }^{\mathrm{C}}$ Fungicide Resistance Action Committee 


\section{Harvesting}

Soybean in different plots was harvested using an ALMACO Research Plot Combine. Yields were adjusted to $13 \%$ grain moisture and measured in bushel per acre following the formula, Yield (bushel/acre $)=+(100$-grain moisture content at harvest $) \div(100-13) \times$ Harvested grain weight (pound) per plot $\div 60 \div$ (plot length $\mathrm{ft}$. $\times$ plot width ft. $\div 43,560$. Where, $100-13$ is adjusted grain moisture content to $13 \%, 60=$ pounds per bushel, $43,560=$ area per acre in $\mathrm{ft}^{2}$.

Subsequently, the yields in bushel/acre from the above were converted to $\mathrm{mt} / \mathrm{ha}$ following the formula; Yield $(\mathrm{mt} / \mathrm{ha})=$ Yield $($ bushel/acre $) \times 0.0272155 \times 2.47$. Where, 0.0272155 is the weight in metric ton per bushel (US grains council https:/grains.org/markets-tools-data/ tools/converting-grain-units/), and 2.47 is conversion from 1 ha to acres.

\section{Tillage and weed management}

At West Curtiss Farm, fields received Generic Prowl at 2.9 1/ha and 0.31 /ha of Sonic on May 6th and field cultivated the same day. Post-planting on June 22, sprayed 1.0 l/ha Clethodim and 1.2 l/ha of Flexstar. Fields at West Curtiss got a 21-70-120-17.5-1.75 (N-P-K-S-Zn) in fall.

\section{Data analysis}

Effects of fungicide seed treatments on soybean stand counts, plant vigor, incidence of Pythium damping-off, and grain yields were analyzed using PROC ANOVA in SAS 9.4. (SAS, LLC, Cray, NY). Fisher's least significant difference was used to detect the significant differences among the means $(P<0.05)$.

\section{Abbreviations}

ANOVA: Analysis of variance; DAP: Days after planting; DMI: Demethylation inhibitors; NCBI: National Center for Biotechnology Information;

PARP: Pimaricin, ampicillin, rifampicin, pentachloronitrobenzene; PDA: Potato dextrose agar; Qol: Quinone outside inhibitors; RCBD: Randomized complete block design; SDHI: Succinate dehydrogenase inhibitors; SDW: Sterilized deionized water; WAP: Week after planting

\section{Acknowledgements}

Not applicable.

\section{Funding}

This study was partly supported by industry dollars (no specific grant number available at this time).

\section{Availability of data and materials}

The datasets used and/or analyzed during the current study are available from the corresponding author on reasonable request.

\section{Authors' contributions}

The first two authors processed diseased samples for pathogen isolation, conducted greenhouse and field tests, the third author did sequencing and the fourth author supervised the project. It was a team work and all authors shared their respective expertise in drafting and approved the final draft of the manuscript for submission.

\section{Ethics approval and consent to participate}

This article does not contain any studies with human participants or animals performed by any of the authors.

\section{Consent for publication}

Not applicable.

\section{Competing interests}

The authors declare that they have no competing interests.

Received: 20 July 2018 Accepted: 12 December 2018

Published online: 14 February 2019

\section{References}

Anonymous. Active ingredient data package metalaxyl \& mefenoxam (version \#4). In: New York State Department of Environmental Conservation; 2015. http:// www.dec.ny.gov/docs/materials_minerals_pdf/mefenoxamdata.pdf. Accessed 18 Jan 2018

Anonymous. Soybeans seed treatment market-global industry growth. In: Trends and forecasts (2017-2022); 2017. https://www.mordorintelligence.com/ industry-reports/global-soybeans-seed-treatment-market-industry. Accessed 18 Jan 2018.

Bates GB, Rothrock CS, Rupe JC. Resistance of the soybean cultivar archer to Pythium damping-off and root rot caused by several Pythium spp. Plant Dis. 2008:92:763-6.

Beck C, Oerke EC, Dehne HW. Impact of strobilurins on physiology and yield formation of wheat. Meded Rijksuniv Gent Fak Landbouwkd Toegep Biol Wet. 2002;67:181-7.

Biesbrock JA, FFJr H. Influence of continuous and periodic soil water conditions on root necrosis of holly caused by Pythium spp. Can J Bot. 1970a;48:1641-5.

Biesbrock JA, FFJr H. Influence of soil water and temperature on root necrosis of peach caused by Pythium spp. Phytopathology. 1970b;60:880-2.

Bradley CA. Effect of fungicide seed treatments on stand establishment, seedling disease, and yield of soybean in North Dakota. Plant Dis. 2008;92:120-5.

Bradley CA. Fungicide seed treatment considerations for soybean. The Bulletin. 2010; Issue no. 2. http://bulletin.ipm.illinois.edu/article.php?id=1274. Accessed 27 Dec 2017.

Bradley CA, Wax L, Ebelhar S, Bollero G, Pedersen W. The effect of fungicide seed protectants, seeding rates, and reduced rates of herbicides on no-till soybean. Crop Prot. 2001;20:615-22.

Broders KD, Wallhead MW, Austin GD, Lipps PE, Paul PA, Mullen RW, et al. Association of soil chemical and physical properties with Pythium species diversity, community composition, and disease incidence. Phytopathology. 2009:99:957-67.

Brown GE, Kennedy BW. Effect of oxygen on Pythium seed rot of soybean. Phytopathology. 1966:56:407-11.

Carmona MA, Sautua FJ, Grijalba PE, Cassina M, Pérez-Hernández O. Effect of potassium and manganese phosphites in the control of Pythium dampingoff in soybean: a feasible alternative to fungicide seed treatments. Pest Manag Sci. 2018;74:366-74.

Coker C, Cartwright R, Kirkpatrick T, Rupe JC. Soybean diseases and their control. In: Arkansas soybean production handbook. University of Arkansas Division of agriculture cooperative extension service. USA: Little Rock; 2001. p. 70-83.

Coker C, Rupe JC, Monfort S, Kirkpatrick TL. Arkansas plant disease control products guide. University of Arkansas Division of agriculture cooperative extension service. In: USA: Little Rock; 2010.

Conrath U, Amoroso G, Köhle H, Sültemeyer DF. Non-invasive online detection of nitric oxide from plants and some other organisms by mass spectrometry. Plant J. 2004:38:1015-22.

Cooke DE, Drenth A, Duncan JM, Wagels G, Brasier CM. A molecular phylogeny of Phytophthora and related oomycetes. Fungal Genet Biol. 2000;30:17-32.

Díaz Arias MM, Leandro LF, Munkvold GP. Aggressiveness of fusarium species and impact of root infection on growth and yield of soybeans. Phytopathology. 2013;103:822-32.

Dorrance AE. Cold spring rains brought perfect conditions for Pythium in Ohio and a few more surprises. Corn Newsletter. 2014:2014-39.

Dorrance AE, Kleinhenz M, McClure S, Tuttle N. Temperature, moisture, and seed treatment effects on Rhizoctonia solani root rot of soybean. Plant Dis. 2003a;87:533-8. 
Dorrance AE, McClure SA. Beneficial effects of fungicide seed treatments for soybean cultivars with partial resistance to Phytophthora sojae. Plant Dis. 2001;85:1063-8

Dorrance AE, McClure SA, Desilva A. Pathogenic diversity of Phytophthora sojae in Ohio soybean fields. Plant Dis. 2003b;87:139-46.

Erwin DC, Ribeiro OK. Phytophthora diseases worldwide. St Paul, MN. USA: The American Phytopathological Society; 1996.

Fehr W, Caviness C, Burmood D, Pennington J. Stage of development descriptions for soybeans, Glycine max (L.) Merrill. Crop Sci. 1971;11:929-31.

Gerhard M, Habermeyer J, Zinkernagel V. The impact of strobilurins on plant vitality on winter wheat under field conditions. In: Lyr H, Russell PE, Dehnel HW, Sisler HD, editors. Modern fungicides and antifungal compounds II. 12th Int. Reinhardsbrunn Symp., Friedrichroda, Thuringia, Germany, 24-29 may 1998. Andover, UK: intercept Itd; 1999. p. 197-208.

Grossmann K, Kwiatkowski J, Caspar G. Regulation of phytohormone levels, leaf senescence and transpiration by the strobilurin kresoxim-methyl in wheat (Triticum aestivum). J Plant Physiol. 1999;154:805-8.

Hartman GL. Worldwide importance of soybean pathogens and pests. In: Compendium of soybean diseases and pests, 5th ed. St Paul, MN. USA: The American Phytopathological Society; 2015. p. 4-5.

Herms S, Seehaus K, Koehle H, Conrath UA. Strobilurin fungicide enhances the resistance of tobacco against Tobacco mosaic virus and Pseudomonas syringae pv tabaci. Plant Physiol. 2002;130:120-7.

Jeffers SN, Martin SB. Comparison of two media selective for Phytophthora and Pythium species. Plant Dis. 1986;70:1038-43.

Kirkpatrick MT, Rupe JC, Rothrock CS. Soybean response to flooded soil conditions and the association with soil-borne plant pathogenic genera. Plant Dis. 2006;90:592-6.

Koenning SR, Wrather JA. Suppression of soybean yield potential in the continental United States by plant diseases from 2006 to 2009. Plant Health Progress. 2010. https://doi.org/10.1094/PHP-2010-1122-01-RS.

Matthiesen RL, Ahmad AA, Robertson AE. Temperature affects aggressiveness and fungicide sensitivity of four Pythium spp. that cause soybean and corn damping-off in lowa. Plant Dis. 2016;100:583-91.

Munkvold GP. Seed pathology progress in academia and industry. Annu Rev Phytopathol. 2009:47:285-311

Navi SS. Effect of foliar fungicides at R3 growth stage on soybean disease and yield. Integrated Crop Management News. 2013; http://lib.dr.iastate.edu/ farms_reports/2038. Accessed 27 Dec 2017.

Navi SS. Efficacy tests of foliar fungicides on soybean diseases and yield during 2012 and 2013 growing seasons in Northeast lowa. Integrated Crop Management News. 2014a; http://works.bepress.com/shrishail_navi/33. Accessed 27 Dec 2017

Navi SS. Evaluation of application rates of fungicides on soybean diseases and yields. lowa State Research Farm Progress Report Paper. 2014b. http://lib.dr. iastate.edu/farms_reports/2209. Accessed 27 Dec 2017.

Navi SS, Yang XB. Sudden death syndrome-a growing threat of losses in soybeans. CAB Reviews. 2016. https://doi.org/10.1079/PAVSNNR201611039.

Navi SS, Yang XB, Li X, Jing L. Effect of pyraclostrobin spray either solo or in combination with other chemicals on soybean diseases and yield response in lowa from 2003 to 2013. In: APS annual meeting; 2015. http://www.apsnet. org/meetings/Documents/2015_meeting_abstracts/aps2015abP480.htm. Accessed 27 Dec 2017.

Pederson P. Soybean growth and development. 2007. https://crops.extension. iastate.edu/files/article/SoybeanGrowthandDevelopment_0.pdf. Accessed 18 Jan 2018.

Poag PS, Popp M, Rupe J, Dixon B, Rothrock C, Boger C. Economic evaluation of soybean fungicide seed treatments. Agron J. 2005;97:1647-57.

Powelson ML, Inglis DA. Foliar fungicides as protective seed piece treatments for management of late blight of potatoes. Plant Dis. 1999;83:265-8.

Reade JPH, Milner LJ, Cobb AH. Can picoxystrobin protect winter wheat from environmental stress? The Bcpc international congress: crop. Sci Technol. 2003:863-8.

Robertson AE. Nineteen species of Pythium associated with damped-off soybean seedlings in lowa. Integrated Crop Management News. 2012; http://lib.dr. iastate.edu/cropnews/186. Accessed 9 Jun 2017.

Robertson AE, Matthiesen R, Ahmad A. Nine species of Pythium associated with corn seeding blight in southeastern lowa. In: Integrated crop management news; 2013. http://lib.dr.iastate.edu/cropnews/63. Accessed 9 Jun 2017.

Rojas JA, Jacobs JL, Napieralski S, Karaj B, Bradley CA, Chase T, et al. Oomycete species associated with soybean seedlings in North America-part I: identification and pathogenicity characterization. Phytopathology. 2017a;107:280-92.

Rojas JA, Jacobs JL, Napieralski S, Karaj B, Bradley CA, Chase T, et al. Oomycete species associated with soybean seedlings in North America-part II: diversity and ecology in relation to environmental and edaphic factors. Phytopathology. 2017b;107:293-304.

Rosso ML, Rupe JC. Rothrock CS. Resistance of soybean cultivars to Pythium damping-off and root rot based on Rps1k gene. (Abstr) Phytopathology. 2005;95(suppl):S90

Stranghellini ME, Hancock JG. Radial extent of the bean spermosphere and its relation to the behavior of Pythium ultimum. Phytopathology. 1971;61:165-8.

Sweets L. Soybean seed treatment fungicides. University of Missouri extension. 2006; http://extension.missouri.edu/scott/documents/Ag/Agronomy/ Soybean-Seed-Treatment-Fungicides-2006.pdf. Accessed 9 Jun 2017.

Tripathi RK, Vohra K, Schlosser E. Effect of fungicides on the physiology of plants. III. Mechanism of cytokinin-like antisenescent action of carbendazim on wheat leaves. Z Pflanzenkr Pflanzenpathol Pflanzenschutz. 1980;87:631-9.

USB Six things farmers should know about seed treatments. 2014. http:// unitedsoybean.org/article/six-things-farmers-should-know-about-seedtreatments/. Accessed 30 Mar 2018.

Waterhouse G, Waterston J. Pythium graminicola. In: CMI Descriptions of Pathogenic Fungi and Bacteria. Wallingford: CAB International; 1964. No. 38

Wellesley MA. BCC research publishes a new report on global markets for seed treatment. 2013. http://www.prweb.com/releases/2013/11/prweb11285468. htm. Accessed 31 Oct 2013.

Wrather JA, Koenning SR. Effects of diseases on soybean yields in the United States 1996 to 2007. Plant Health Prog. 2009. https://doi.org/10.1094/PHP2009-0401-01-RS

Wu YX, Von Tiedemann A. Physiological effects of azoxystrobin and epoxiconazole on senescence and the oxidative status of wheat. Pestic Biochem Physiol. 2001;71:1-10.

Yang XB. Rhizoctonia damping-off and root rot. In: Hartman GL, Sinclair JB, Rupe JC, editors. Compendium of soybean diseases, 4th ed. St Paul, MN. USA: The American Phytopathological Society; 1999. p. 45-6.

Yang XB. Identifying soybean seedling diseases. Integrated Crop Management News. 1766. 2002; https://lib.dr.iastate.edu/cropnews/1766. Accessed 30 Mar 2018.

Yang XB. 2009. Minimize SDS and white mold risk to same field. Integrated Crop Management. 2009. http://www.extension.iastate.edu/CropNews/2009/ 1209yang.htm. Accessed 9 Dec 2009.

Zhang BQ, Chen WD, Yang XB. Occurrence of Pythium species in long-term maize and soybean monoculture and maize/soybean rotation. Mycol Res. 1998;102:1450-2.

Zhang BQ, Yang XB. Pathogenicity of Pythium populations from corn-soybean rotation fields. Plant Dis. 2000;84:94-9.

Ready to submit your research? Choose BMC and benefit from

- fast, convenient online submission

- thorough peer review by experienced researchers in your field

- rapid publication on acceptance

- support for research data, including large and complex data types

- gold Open Access which fosters wider collaboration and increased citations

- maximum visibility for your research: over $100 \mathrm{M}$ website views per year

At $\mathrm{BMC}$, research is always in progress.

Learn more biomedcentral.com/submission 